Article

\title{
Precision Irrigation Strategies for Sustainable Water Budgeting of Potato Crop in Prince Edward Island
}

\author{
Hassan Afzaal ${ }^{1}{ }^{(\mathbb{C}, \text { Aitazaz A. Farooque }}{ }^{1, *}$, Farhat Abbas ${ }^{1, *} \mathbb{C}$, Bishnu Acharya ${ }^{1}$ and Travis Esau ${ }^{2}$ \\ 1 Faculty of Sustainable Design Engineering, University of Prince Edward Island, \\ Charlottetown, PE C1A4P3, Canada; hafzaal2@upei.ca (H.A.); bacharya@upei.ca (B.A.) \\ 2 Engineering Department, Dalhousie University, Agriculture Campus, Truro, NS B2N5E3, Canada; \\ tesau@dal.ca \\ * Correspondence: afarooque@upei.ca (A.A.F.); fabbas@upei.ca (F.A.); Tel.: +1-902-566-6084 (A.A.F.)
}

Received: 18 February 2020; Accepted: 16 March 2020; Published: 19 March 2020

\begin{abstract}
Climate change induced uneven patterns of rainfall emphasize the use of supplemental irrigation in rainfed agriculture. The Penman-Monteith method was used to calculate supplemental irrigation for water budgeting of a potato crop in Prince Edward Island, Canada. Cumulative gaps between rainfall and crop evapotranspiration (ETc) during August and September of the study years were due to high crop coefficient factor, justifying the need for supplemental irrigation. Pressurized irrigation systems, including sprinklers, fertigation, and drip irrigation were installed, to evaluate the impact of scheduled supplemental irrigation in offsetting deficits in irrigation water requirements in comparison with conventional practice of rainfed cultivation (control). A two-way ANOVA examined the effect of irrigation methods and year on potato tuber yield, water productivity, tuber quality, and payout. Sprinkler and fertigation systems performed better than drip and control treatments. In terms of payout returns and potato tuber quality (percentage of marketable potatoes), the sprinkler treatment performed significantly better than the other treatments. However, for water productivity, fertigation treatment performed significantly better than control and sprinkler treatments during both years. The use of supplemental irrigation is recommended for profitable cultivation of potatoes in soil, agricultural, and environmental conditions resembling to those of Prince Edward Island.
\end{abstract}

Keywords: evapotranspiration; irrigation methods; fertigation; irrigation scheduling; rainfed agriculture; sprinklers; water productivity

\section{Introduction}

Potato (Solanum tuberosum L.) is the world's fourth most-important food crop [1]. The utilization of the potato in human nourishment and the scratch manufacturing distinguishes it from other vital crops on the planet [2]. The potato industry significantly promotes the economy of Prince Edward Island, as it contributes about $10.8 \%$ to the GDP of this province, with more than one billion direct and indirect economic benefits engaging $12 \%$ of total workforce of the island [3]. Currently, Prince Edward Island is producing approximately $25 \%$ of total potatoes grown by Canada each year [4]. The majority of potato production in Prince Edward Island is rainfed. Potato is a very sensitive crop in terms of both yield and quality under limited water conditions [5], and it is suggested that soil water should not be depleted by more than $30 \%-50 \%$ for optimum potato yield [6]. The findings of study by Shock et al. [7] suggested the higher risk of reduced potato yields in case of water shortages. Ojala et al. [8] evaluated the effects of irrigation on yield of potato tuber (cultivar: Russet Burbank) and its quality, and they reported that the tuber yield was sensitive to deficit irrigation during tuber initiation and bulking stages. Their results suggested that the irrigation deficits should be avoided during midseason tuber bulking stage, to achieve optimal potato tuber yield. The majority of potato production in Prince 
Edward Island is rainfed, and the crop needs regular rainfall for maximum yield. Climate change is evident in Prince Edward Island and will cause more hot days, lesser cold days, and changes in precipitation patterns [9]. However, supplemental irrigation can be used to replenish the crop water requirements in case of delayed rainfall. For sustainability of potato production in Prince Edward Island, the regular rainfall, in addition to supplemental irrigation, is a viable option.

Several research studies have been conducted to assess the effects of supplemental irrigation on potato tuber yield. For example, Belanger et al. [10] tested the irrigation and nitrogen fertilizers' effects on two potato cultivar yields in New Brunswick Canada. Results indicated the increased potato yield from 31.9 to $38.4 \mathrm{Mg} \mathrm{ha}^{-1}$ and marketable yield from 25.6 to $30.7 \mathrm{Mg} \mathrm{ha}^{-1}$. Similar results were recorded for both potato cultivars. Porter et al. [11] studied the soil management and supplemental irrigation effect on potato tuber yield and quality. Supplemental irrigation significantly increased total yields by 10.6 to $11.6 \mathrm{Mg} \mathrm{ha}^{-1}$. Similarly, potato tuber size was significantly increased from the result of supplemental irrigation, while decreased specific gravity of potato tubers was observed. Opena et al. [12] assessed the effects of supplemental irrigation and soil amendments on potato root growth and noticed a significant increase in root length density in treatments of supplemental irrigation. The leaf area index and root length density were significantly correlated with potato tuber yields, indicating that the early growth season was an important period for the potato crop with respect to irrigation. Allen and Lambert [13] presented the framework of irrigation scheduling in consideration with crop economics, soil state, and weather forecast, for efficient decision making with regard to crop husbandry. Their model used each irrigation event as an attempt to optimize resources with increased economic gains. They reported that the amount of supplemental irrigation largely depended upon the amount of rainfall and crop water requirements. Therefore, accurate estimation of reference evapotranspiration (ETo) is inevitable for precise water management.

The reference evapotranspiration is a major contributor to water balance, as well as to the surface energy equation. It provides useful information regarding irrigation quantification and efficient water resources management. Several direct and indirect methods of ETo estimation have been introduced in an attempt to increase accuracy in ETo estimation. The most common and direct ETo estimation method uses the lysimeter apparatus; however, high maintenance and operational costs have limited its application [14]. Several indirect mathematical models have also been introduced for ETo estimation and provided an adequate alternative of lysimeter method due to ease of application and time-saving [15]. The Food and Agriculture Organization (FAO) standardized method, namely the Penman-Monteith method, is one of most acceptable models for ETo modelling [16]. The Penman-Monteith method requires several climatic variables, such as relative humidity, temperature, solar radiation, wind speed, and more information about the area. The Hargreaves equation is another simple alternative over Penman-Monteith by estimating ETo with temperature data only. The choice of method solely depends upon the data availability and accuracy of estimation. Kashyap and Panda [17] compared ten different climatological methods of estimating ETo. Their result suggested that the Penman Monteith equation was the best estimation method in comparison with other methods.

Several irrigation methods have been tested previously to replenish the crop water requirements on an on-need basis. Onder et al. [18] studied the effect of surface and subsurface drip irrigation methods with four different water stress levels on potato yield and yield components. The four stress levels were tested, including full irrigation, $66 \%$ of full irrigation, $33 \%$ of full irrigation, and no irrigation. No significant differences of irrigation methods were observed on yield. However, the result depicted that the drip irrigation has several advantages over subsurface irrigation in terms of installation and replacement costs. Water stress significantly affected the potato yield and yield components of early potato yield production. More than 33\% deficiency of irrigation requirements of potato crop is not suggested. Stylianou et al. [19] evaluated the effects of sprinkler and trickle irrigation on potato yield on the basis of pan evaporation. The results suggested that the trickle irrigation was not the suitable method for potatoes, as the soil cracked and exposed the potato tubers to be attacked by the moths. Unlu et al. [20] evaluated the effects of trickle and sprinkler irrigation in the middle Anatolian, 
Turkey. In this study, three irrigation methods were selected, namely sprinkler, drip, and fertigation. The highest yield was measured in sprinkler-irrigated plots at the $60 \mathrm{~g} \mathrm{~m}^{-3}$ nitrogen concentration levels. Trifonov et al. [21] studied potato crop characteristics under low discharge from a drip irrigation system, to determine the optimal dosses of irrigation and fertigation. Their results suggested that drip and fertigation systems were water-productive systems when available agricultural soils were not a limiting factor. Waddell et al. [22] conducted a two-year study to evaluate the impacts' different irrigation methods and nitrogen management on potato tuber yield, quality and nitrogen uptake. They found nonsignificant differences in potato yield under sprinkler and drip irrigation systems. However, their drip irrigation treatment had higher water productivity than sprinkler irrigation treatment. Ierna et al. [23] evaluated the levels of irrigation and fertilizers to assess potato tuber yield, water, and fertilizer productivity. Their results suggested that the irrigation levels based on $50 \%$ of maximum ETo and medium fertilizers levels $\left(100-150 \mathrm{Kg} \mathrm{ha}^{-1}\right)$ was a better management practice for early potato cultivation and optimum yields.

Since Prince Edward Island is surrounded by ocean, it requires efficient and careful water resources use (e.g., groundwater pumping for supplemental irrigation of crops), to avoid saltwater intrusion into its aquifer. Agriculture in Prince Edward Island is mostly rainfed, and changing patterns of rainfall due to climate change [24] have necessitated pumping of water from high-capacity wells to provide supplemental irrigations to agricultural crops during dry summer months. This has raised concerns about groundwater sustainability, its responsible use, and saltwater intrusion in the system. A recent study by Afzaal et al. [25] pointed out the lower groundwater levels than expected in the summer season as a consequence of pumping. This situation has created challenges for water resources managers to meet the supplemental irrigation demands of crops for their sustainable production. It is hypothesized that devising precision irrigation strategies and their evaluation for sustainable water budgeting of potato crop in Prince Edward Island will answer some concerns mentioned above. Therefore, the specific objective of this study was to quantify the crop water requirements of potatoes, to assess the needs of supplemental irrigation in Prince Edward Island through the use of three irrigation methods, namely drip, sprinkler, and fertigation, in relation to potato tuber yield, potato tuber quality, water sustainability, and payout returns. It is anticipated that the results of this study will provide the guidelines to water resource managers for sustainable water management. There has been limited work in the literature for Prince Edward Island region, making this work novel and useful for potato growers, as well as for policy makers.

\section{Materials and Methods}

\subsection{Study Field, Experimental Design, and Soil Properties}

The experiments reported here were conducted in 2018 and 2019, on a research farm at Kensington, Prince Edward Island $\left(46.417032^{\circ} \mathrm{N} 63.67658^{\circ} \mathrm{W}\right.$ ), Canada (Figure 1). The field of $1003.35 \mathrm{~m}^{2}$ was divided into four treatment plots, namely sprinkler, drip, fertigation, and control triplicated on $9.1 \mathrm{~m}$ by $4.5 \mathrm{~m}$ plots (Figure 1). Patches of $1 \mathrm{~m}$ were left between treatment plots, to serve as buffer zones and walkways for data collection, agronomic operation, and field management activities. The potato seeds were planted in $0.30 \mathrm{~m}$ wide and $9.1 \mathrm{~m}$ long beds. In total, there were four beds of potatoes in each triplicated treatment, with 25 potato seeds planted in each seedbed. The center-to-center distance between two seedbeds was $1 \mathrm{~m}$, and the plant-to-plant distance was maintained as $0.20 \mathrm{~m}$. The experiments were under complete randomized design, with two factorial arrangements. The irrigation methods and the growing years were the two independent factors with continuous response variables, including potato tuber yield, tuber quality, water productivity, and payout returns (Figure 1). 

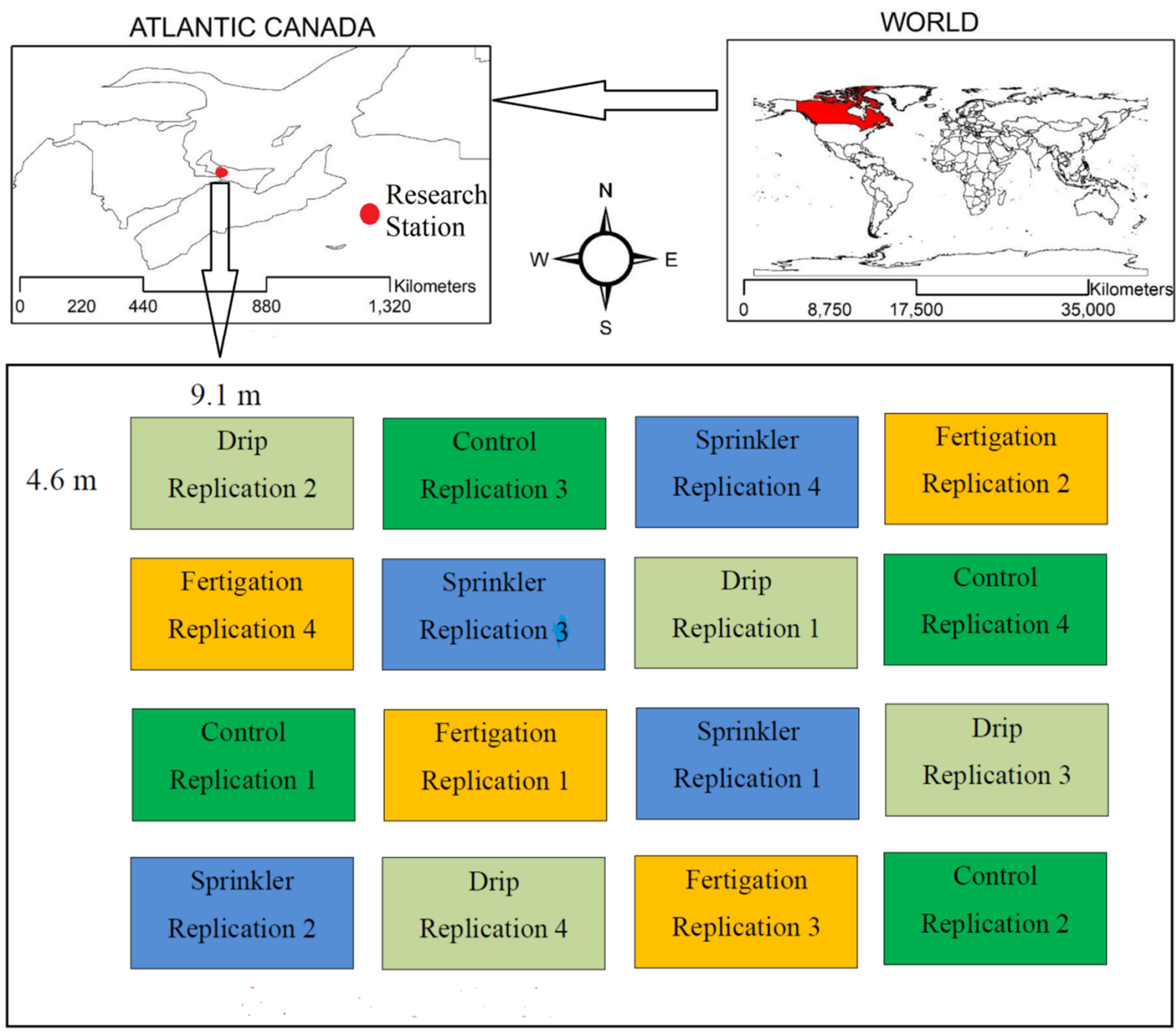

Figure 1. The location of experimental field and experimental layout.

Two soil samples were collected from each replication and homogenized prior to their analyses, for soil macro-nutrients (nitrogen, N; phosphorous, $\mathrm{P}$; and potassium, K), micro-nutrients (boron, B; copper, $\mathrm{Cu}$; zinc, $\mathrm{Zn}$; magnesium, $\mathrm{Mg}$; iron, Fe; calcium, $\mathrm{Ca}$ ), organic matter, and soil $\mathrm{pH}$. Soil analyses were conducted by Prince Edward Island Analytical Laboratories, at the beginning of experiment, in May 2018. The multi-elemental analysis technique IC-POE [26,27] was used for soil micro- and macro-nutrient analysis, using IC-POE equipment (Model 6500; ThermoFisher Scientific; Waltham, Massachusetts, United States). The IC-POE technique uses optical emission spectrometry analysis to quantify nutrients in soil. The titration method [27], using a PC titration instrument (ManSci Inc. Orlando, Florida, US), was used to determine soil $\mathrm{pH}$. Soil organic content was determined by using the loss-on-ignition technique [28], which uses a Combustion Analyzer model CN628 (LECO Corporation, St. Joseph, Michigan, United States) to completely burn organic matter present in soil samples. The Sodium Acetate Method [27] was used to determine cation exchange capacity (CEC) of soil. Soil analysis results (Table 1) were used to determine crop nutrient requirement. 
Table 1. Descriptive statistics of soil variables for the four experimental treatments.

\begin{tabular}{|c|c|c|c|c|}
\hline Variable & Irrigation Methods & Mean \pm SD & Minimum & Maximum \\
\hline \multirow{4}{*}{$\begin{array}{l}\text { Organic matter content } \\
\qquad(\%)\end{array}$} & Control & $2.9 \pm 0.30$ & 2.50 & 3.40 \\
\hline & Drip & $2.8 \pm 0.18$ & 2.50 & 3.10 \\
\hline & Fertigation & $2.8 \pm 0.28$ & 2.50 & 3.40 \\
\hline & Sprinkler & $2.8 \pm 0.23$ & 2.50 & 3.00 \\
\hline \multirow{4}{*}{$\begin{array}{l}\text { Phosphate } \\
(\mathrm{mg} / \mathrm{kg})\end{array}$} & Control & $490 \pm 47.4$ & 401 & 548 \\
\hline & Drip & $456 \pm 46.9$ & 378 & 513 \\
\hline & Fertigation & $488 \pm 43.1$ & 402 & 541 \\
\hline & Sprinkler & $459 \pm 49.0$ & 383 & 519 \\
\hline \multirow{4}{*}{$\begin{array}{l}\text { Phosphorous } \\
(\mathrm{mg} / \mathrm{kg})\end{array}$} & Control & $135 \pm 0$ & 135 & 135 \\
\hline & Drip & $135 \pm 0$ & 135 & 135 \\
\hline & Fertigation & $135 \pm 0$ & 135 & 135 \\
\hline & Sprinkler & $135 \pm 0$ & 135 & 135 \\
\hline \multirow{4}{*}{$\begin{array}{l}\text { Potash } \\
(\mathrm{mg} / \mathrm{kg})\end{array}$} & Control & $182 \pm 19.1$ & 151 & 213 \\
\hline & Drip & $147 \pm 15.3$ & 115 & 168 \\
\hline & Fertigation & $157 \pm 12.9$ & 142 & 179 \\
\hline & Sprinkler & $152 \pm 15.6$ & 128 & 166 \\
\hline \multirow{4}{*}{$\begin{array}{l}\text { Copper } \\
(\mathrm{mg} / \mathrm{kg})\end{array}$} & Control & $0.42 \pm 0.07$ & 0.40 & 0.60 \\
\hline & Drip & $0.45 \pm 0.07$ & 0.40 & 0.60 \\
\hline & Fertigation & $0.42 \pm 0.07$ & 0.40 & 0.60 \\
\hline & Sprinkler & $0.45 \pm 0.07$ & 0.40 & 0.60 \\
\hline \multirow{4}{*}{ Soil $\mathrm{pH}$} & Control & $6.60 \pm 0.05$ & 6.50 & 6.70 \\
\hline & Drip & $6.64 \pm 0.05$ & 6.60 & 6.70 \\
\hline & Fertigation & $6.59 \pm 0.06$ & 6.50 & 6.70 \\
\hline & Sprinkler & $6.73 \pm 0.04$ & 6.70 & 6.80 \\
\hline \multirow{4}{*}{$\begin{array}{c}\text { Cation exchange } \\
\text { capacity (meq/100g) }\end{array}$} & Control & $9.37 \pm 0.51$ & 9.00 & 10.0 \\
\hline & Drip & $8.87 \pm 0.64$ & 8.00 & 10.0 \\
\hline & Fertigation & $9.50 \pm 0.53$ & 9.00 & 10.0 \\
\hline & Sprinkler & $7.80 \pm 0.30$ & 7.00 & 8.00 \\
\hline
\end{tabular}

\subsection{Crop Water Requirements}

Penman-Monteith method was used to estimate the $\mathrm{ET}_{\mathrm{C}}$, which is an integral part of the soil-water-balance equation, which can be expressed as follows [29]:

$$
\mathrm{P}=\mathrm{Q}+\mathrm{ET}_{\mathrm{c}}+\Delta \mathrm{S}
$$

where $\mathrm{P}$ is precipitation; $\mathrm{Q}$ is runoff; and $\Delta \mathrm{S}$ is change in soil moisture storage. $\mathrm{ET}_{\mathrm{C}}$ is crop evapotranspiration, which is calculated with the relationship involving crop coefficient factor $\left(\mathrm{k}_{\mathrm{C}}\right)$ and ETo [17].

$$
\mathrm{ETc}=\mathrm{ETo} * \mathrm{kc}
$$

The ETo is calculated as follows:

$$
\operatorname{ETo}\left(\frac{m m}{\text { day }}\right)=\frac{\Delta\left(R_{n}-G\right)+\rho_{a} c_{p}\left(\frac{e s-e a}{r a}\right)}{\Delta+\gamma\left(1+\frac{r_{s}}{r_{a}}\right)}
$$

where $\mathrm{ETo}=$ reference evapotranspiration; $\Delta=$ slope of vapor saturation pressure; $R_{n}=$ net radiation; $\mathrm{G}$ $=$ soil heat flux; $\rho_{a}=$ mean air density at constant air pressure; $c_{p}=$ specific heat of the air; $e s-e a=$ vapor pressure deficit; $\gamma=$ psychrometric constant; $r_{s}=$ surface resistance; $r_{a}=$ aerodynamic resistance.

The crop factor depends on the crop growth stage and variates among different growth stages. Potato growth stages may divide into initial (20 days after planting; DAP), development (21-50 DAP), 
mid (51-110 DAP), and late stage (111-140 DAP) [5]. In the initial potato stage, the value of kc fluctuates between 0.4 and 0.5 ; in the development stage, $\mathrm{k}_{\mathrm{c}}$ varies between 0.7 and 0.8 ; in the mid stage, $\mathrm{kc}$ ranges between 1.05 and 1.2; and in the late season, $\mathrm{kc}$ varies between 0.7 and 0.75 [5]. The recommended depletion levels for potato crops are suggested to be $30-50 \%$ of soil field capacity [6].

\subsection{Water Productivity}

The water productivity $\left(\mathrm{kg} / \mathrm{m}^{3} ; \mathrm{kg}\right.$ of crop yield $/ \mathrm{m}^{3}$ of total water available to the crop) is a well-known parameter to assess the effectiveness of irrigation systems in consideration with sustainable use of water and is calculated as follows [30]:

$$
\text { Water Prodictivity }=\frac{\mathrm{Ya}}{\mathrm{P}+\mathrm{I}+\Delta \mathrm{S}}
$$

where $\mathrm{Ya}=$ Actual yield $(\mathrm{kg}) ; \mathrm{P}=$ Precipitation $\left(\mathrm{m}^{3}\right) ; \mathrm{I}=$ Applied irrigation $\left(\mathrm{m}^{3}\right) ; \Delta \mathrm{S}=$ Difference in soil water storage between planting and harvesting $\left(\mathrm{m}^{3}\right)$.

\subsection{Irrigation Methods}

Three irrigation methods, namely sprinkler, drip, and fertigation were tested in comparison with a control (no supplemental irrigation, i.e., rainfall only) method, to evaluate the effects of irrigation methods on potato tuber yield, potato tuber quality, and water sustainability. All three irrigation systems were installed by using a series of piping networks with variable rate pressure pumps and water tanks. The designing of pumps and tanks was based on the gaps between ETo and rainfall calculated for the period 2011-2017. The equation of continuity (Equation (5)) was used to determine the pipe diameters for the irrigation systems:

$$
\mathrm{Q}=A * \mathrm{~V}
$$

where $\mathrm{Q}$ is flow in $\mathrm{m}^{3} / \mathrm{s} ; A$ is area in $\mathrm{m}^{2}$; and $\mathrm{V}$ is velocity in $\mathrm{m} / \mathrm{s}$.

The sprinkler irrigation system was designed for four replications, while the sprinkler guns were connected with $38.1 \mathrm{~mm}$ PVC pipe. Small spray heads (Rain Bird Model 1812PRS 1800 Series) were used in conjunction with a $0.3 \mathrm{~m}$ extension, to ensure the sprinkler height with respect to maximum height of potato plants. Rain Bird adjustable arc spray nozzles (Model 10VAN) with range of $3 \mathrm{~m}$ were used with overlapping setups. Five spray heads were used in one replication with $70 \%$ overlap of wetting pattern radius. Pressure and flow calibrations were conducted in the laboratory prior to installation of the system in experimental plots.

The drip irrigation system comprised $12.7 \mathrm{~mm}$ poly drip tubing with pressure compensating emitters (Model IDROP-10 4 LPH) inserted in the drip tubes based on plant-to-plant distances within a row. Laboratory calibrations for flow tests were conducted for the nearest and the farthest drip emitters, from the pressure pump, in order to ensure equitable flow and pressures in emitters and drip lines. Four lines of poly drip tubing were installed for one replication, with 45 emitters in each line. All drip lines were connected by $19.05 \mathrm{~mm}$ diameter PVC pipes. Different pipe sizes were used for the sprinkler, drip and fertigation systems, to ensure the equitable and laminar flow in pipes of different interconnected irrigation systems. In the fertigation system, fertigation tanks (Model EZFLO-2005-HB 3/4 Gallon) were added for liquid fertilizer application with similar design as in the drip irrigation system.

\subsection{Crop Nutrient Requirements and Husbandry}

Pre-sowing soil analysis results (Table 1) were used to calculate nitrogen, phosphate and potassium application rates for the experimental treatments by following the nutrient recommendations from the Prince Edward Island Department of Agriculture and Fisheries [31]. Because of no substantial variations between NPK concentrations among the experimental treatment plots during both years, 
almost the same application rates were calculated and used for the respective treatments. Except in fertigation treatment plots, the NPKs were applied with broadcasting method that refers to uniform spreading of granular fertilizer over the soil surface in contrast of localized application of fertilizer that refers to spreading fertilizer in a band or a circle near around the seed/field furrows or plants. Further information of nutrient application is provided on Table 2.

Table 2. Soil nutrient balance for cropping year 2018 and 2019.

\begin{tabular}{|c|c|c|c|c|c|c|}
\hline Year & Dates & Treatments & $\mathrm{N}, \mathrm{kg} / \mathrm{ha}$ & $\mathrm{P}, \mathrm{kg} / \mathrm{ha}$ & $\mathrm{K}, \mathrm{kg} / \mathrm{ha}$ & Total Urea, kg/ha \\
\hline \multirow{4}{*}{2018} & June 11 and July 28 & Control & 160 & 135 & 135 & 350 \\
\hline & June 11 and July 28 & Drip & 160 & 135 & 135 & 350 \\
\hline & June 11, July 15 and 31 & Fertigation & 160 & 135 & 135 & 350 \\
\hline & June 11 and July 28 & Sprinkler & 160 & 135 & 135 & 350 \\
\hline \multirow{4}{*}{2019} & June 10 and July 25 & Control & 180 & 135 & 135 & 390 \\
\hline & June 10 and July 25 & Drip & 180 & 135 & 135 & 390 \\
\hline & June 10, July 20 and 29 & Fertigation & 180 & 135 & 135 & 390 \\
\hline & June 10 and July 25 & Sprinkler & 180 & 135 & 135 & 390 \\
\hline
\end{tabular}

\subsection{Crop Production}

Seed potatoes (Russet Burbank) were sown on June 11, 2018, and on June 10, 2019, for the two respective growing seasons. The rest of crop husbandry operations, including maintenance of seed beds/furrows and weeding were done similarly in all treatment plots. All treatments received similar field operations, such as tillage, pesticides, and fungicides. All the treatments were investigated biweekly for disease and fungus attacks.

\subsection{Data Measurements}

Soil moisture levels were recorded with TDR probes (Field Scout 350), at 0, 0.15, and $0.30 \mathrm{~m}$ soil depths each week, during both planting years. Weather data for daily ETo calculations were obtained from the Summerside $\left(46.441111^{\circ} \mathrm{N} 63.838056^{\circ} \mathrm{W}\right)$ weather station, which is $300 \mathrm{~m}$ away from the experimental field. Supplemental irrigation was scheduled to replenish weekly evaporated water from soil and plants. Potato yield samples were collected on October 19, 2018, and October 10, 2019, from one out of 4 randomly selected rows and weighed by using electronic balance with precision of $1.00 \mathrm{~g}$ for different quality parameters, such as good-sized/marketable potatoes that were used to calculate total payout per hectare. Potatoes passing through $50-80 \mathrm{~mm}$ diameter holes of the potato sorter were considered to be of good sized and/or marketable. The potato tuber quality parameters were selected based on United States Departments of Agriculture [32] guidelines. Under these guidelines, the US No. 1 grade potatoes are selected on the basis of similar variety characteristics including their firmness and shape. The US No. 1 grade potatoes should also be free from tuber diseases (blackheart, late blight), internal damages, external damages, loose sprouts, insects, and worms to be considered as marketable potatoes. The potatoes passing through 50-80 mm diameter holes of the potato sorter were considered to be of good size and/or marketable.

Payout returns were calculated based on similar quality standards provided by the United States Department of Agriculture [32]. Potato tubers were tested for specific gravity calculations, internal defects, potato shape, potato size, and disease checks. Equation (6) was used to determine the payout returns per hectare for potato tuber yield samples.

$$
\text { Payout Returns }\left(\frac{C A D}{h a}\right)=\left(\frac{a+b+c}{3}\right) * \text { Net worth of yield sample }\left(\frac{C A D}{h a}\right)
$$


where $a, b$, and c are factors to represent the quality parameters of potato tubers. Specific gravity of potato tubers sample is represented by factor ' $a$ '. Internal and external defect freeness of potato tuber is represented with factor ' $b$ '. Similarly, the potato shape and size are represented by factor ' $c$ '. The values of factor ' $a$ ' and ' $c$ ' may reach higher than 1 , which results in higher payout returns.

\subsection{Statistical Analysis}

Two-way analysis of variance (ANOVA) was used to evaluate the differences in mean values. The ANOVA assumptions, such as independent observations, normal distribution, and within-groups homoscedasticity, were evaluated for each hypothesis. In this study, the group means were compared with Tukey's pairwise comparisons test, which is described as follows:

$$
\mathrm{HSD}=\frac{\mathrm{M}_{i}-\mathrm{M}_{j}}{\sqrt{\frac{\mathrm{MS}_{\mathrm{w}}}{\mathrm{n}}}}
$$

where HSD = honest significant difference; $\mathrm{M}_{i}-\mathrm{M}_{j}=$ difference of pairs of means; $\mathrm{MS}_{\mathrm{w}}=$ mean square with group; and $\mathrm{n}=$ number in treatments.

Minitab 18 (State College, Pennsylvania State University, PA: Minitab, Inc.) was used in the calculation of ANOVA and multiple means comparisons tests.

\section{Results}

\subsection{Descriptive Statistics of Potato Yield and Components}

In 2018, the highest potato tuber yield was observed for the sprinkler irrigation system, i.e., $38,327 \mathrm{~kg} / \mathrm{ha}$, in comparison with other irrigation methods with slightly higher standard deviation of $1096 \mathrm{~kg} / \mathrm{ha}$. In 2019, 12.1\% lower yield was observed for control treatment in comparison with year 2018 (Table 3). No major differences were observed for fertigation and drip treatment yields in 2018 and 2019. In 2019, relatively less rainfall was recorded than in year 2018, which might have caused a lower yield for the control treatment. The residual analysis of potato tuber yield data suggested the applicability of the ANOVA method, e.g., normal distribution, equal variance and independent observation.

Table 3. Descriptive statistics of potato tuber yield and quality data for the four experimental treatments.

\begin{tabular}{|c|c|c|c|c|c|}
\hline Year & Response Variable & Irrigation Method & Mean \pm SD & Minimum & Maximum \\
\hline \multirow{8}{*}{2018} & \multirow{4}{*}{ Yield (kg/ha) } & Control & $35,493 \pm 408 \mathbf{a}$ & 34,889 & 35,782 \\
\hline & & Drip & $35,317 \pm 820 \mathbf{a}$ & 34,130 & 35,943 \\
\hline & & Fertigation & $36,983 \pm 667 \mathbf{a}$ & 36,119 & 37,645 \\
\hline & & Sprinkler & $38,327 \pm 1096 \mathbf{a}$ & 37,173 & 39,744 \\
\hline & \multirow{4}{*}{$\begin{array}{c}\text { Marketable potatoes } \\
(\%)\end{array}$} & Control & $52.8 \pm 5.40$ & 45.3 & 58.2 \\
\hline & & Drip & $55.5 \pm 2.60$ & 52.9 & 59.0 \\
\hline & & Fertigation & $55.0 \pm 1.20$ & 53.3 & 56.0 \\
\hline & & Sprinkler & $64.3 \pm 2.00$ & 61.3 & 65.8 \\
\hline \multirow{8}{*}{2019} & \multirow{4}{*}{ Yield (kg/ha) } & Control & $30,939 \pm 1673 b$ & 28,682 & 32,268 \\
\hline & & Drip & $35,305 \pm 1975 \mathbf{a}$ & 32,820 & 37,470 \\
\hline & & Fertigation & $36,686 \pm 1272 \mathbf{a}$ & 34,989 & 38,072 \\
\hline & & Sprinkler & $34,413 \pm 3407 \mathbf{a b}$ & 31,826 & 38,273 \\
\hline & \multirow{4}{*}{$\begin{array}{c}\text { Marketable potatoes } \\
(\%)\end{array}$} & Control & $69.1 \pm 11.5$ & 52.5 & 77.7 \\
\hline & & Drip & $80.6 \pm 1.20$ & 79.8 & 82.4 \\
\hline & & Fertigation & $74.4 \pm 6.70$ & 70.0 & 84.3 \\
\hline & & Sprinkler & $82.2 \pm 3.20$ & 79.2 & 85.7 \\
\hline
\end{tabular}

Letters $\mathrm{a}, \mathrm{b}$ and $\mathrm{ab}$ in the same columns indicates significant statistical differences $(p<0.05$, Tukey's test) 


\subsection{Gaps between Rainfall and Evapotranspiration}

There was substantial variability in rainfall and ETo for different months of a potato growing season (June-October) during 2011-2017 (Figure 2)—a period considered (i) by Penman-Monteith method for estimation of ETo and (ii) for requirement of water for irrigation systems, pipe diameters, and the size of pump and tank used in this study. The ETo surpassed the rainfall in the month of June for years 2011-2014 and 2016-2017, and the highest gap between rainfall and ETo was observed in the month of July for year 2012-2017. In July, the recorded differences between ETo and rainfall were computed to be $3.655,-92.175,-56.12,-84.96,-73.40,-68.51$, and $-98.69 \mathrm{~mm}$ for years 2011 through 2017, respectively. June and July are the months of plant growth and, thus, irrigation needs.

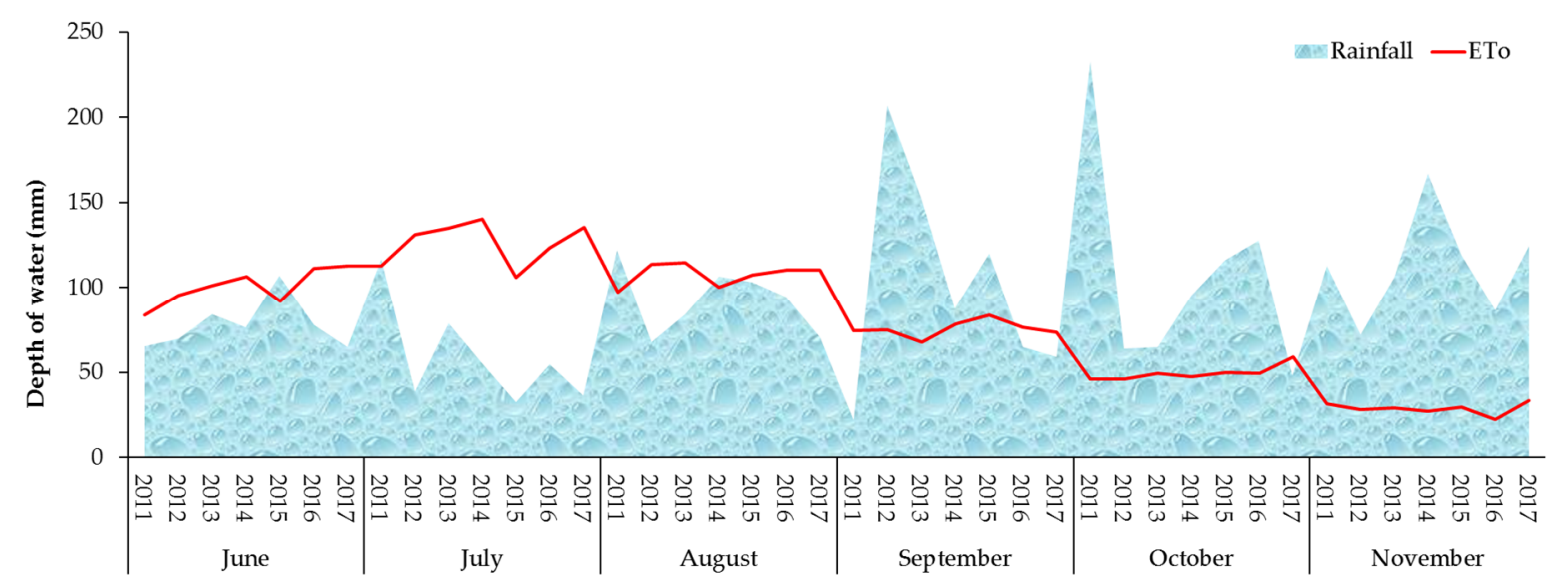

Figure 2. Comparison of rainfall with reference evapotranspiration for the period 2011-2017. Reproduced with permission from Afzaal et al., Applied Sciences; MDPI, 2020 [33].

The potato crop cumulative $\mathrm{ET}_{\mathrm{C}}$ is presented in Figure 3 for whole the cropping years of 2018 and 2019. Major differences were observed between ETo and rainfall in the months of June, July, and August (Figure 2); however, the differences between $\mathrm{ET}_{\mathrm{C}}$ and rainfall were minor (Figure 3a) in the months of July, August, and September 2018, due to low kc factor during initial growth stages of the potato plants. Plants require less water in their initial stages, followed by an increased demand of water in later stages. Due to higher kc factor (1.20) in mid potato stages, higher differences were recorded between $\mathrm{ET}_{\mathrm{C}}$ and rainfall in months of September and October 2018.

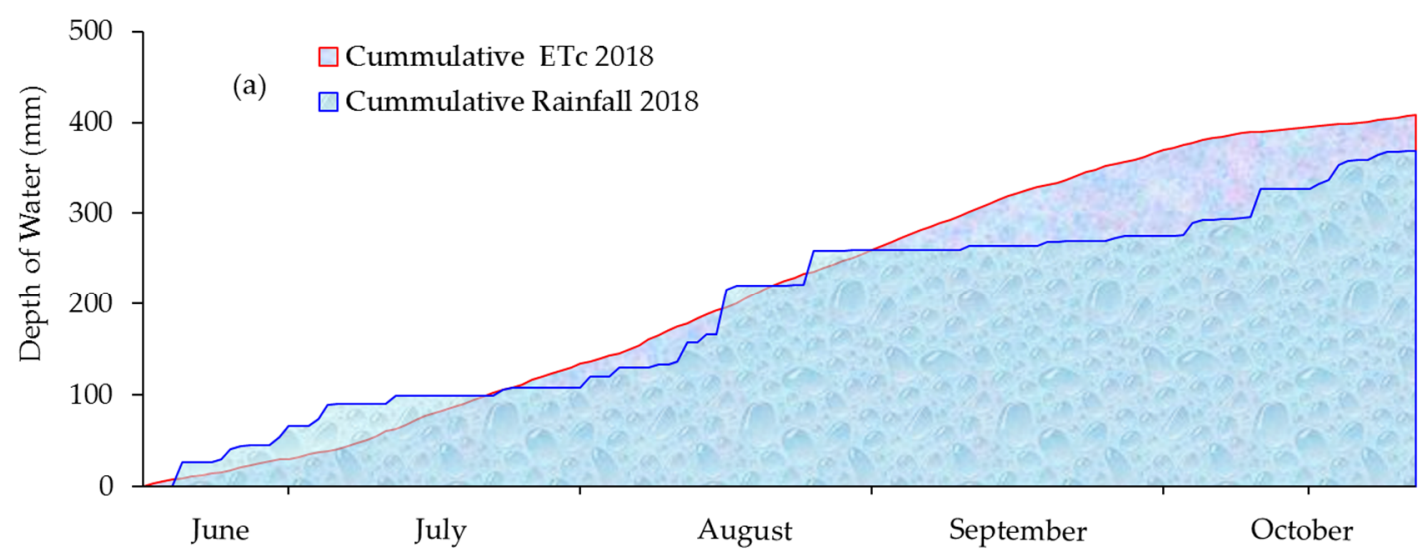

Figure 3. Cont. 


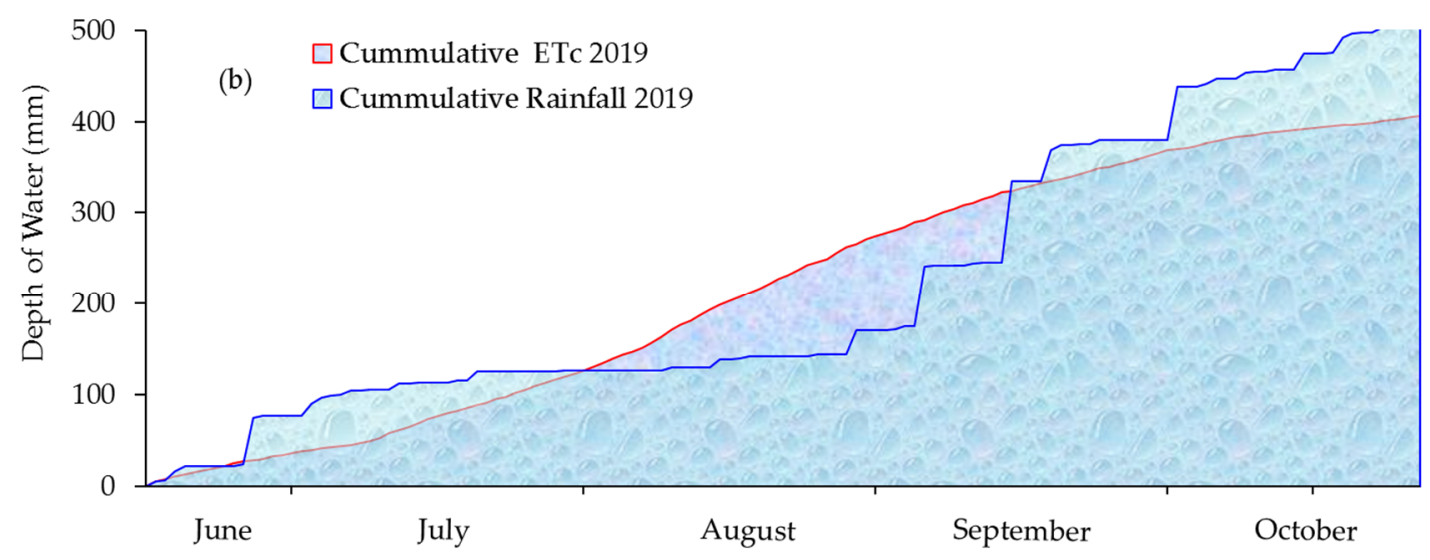

Figure 3. Comparison of rainfall with crop evapotranspiration for years (a) 2018 and (b) 2019.

\subsection{Soil Water Balance}

Water budgeting for an agricultural field provides useful information for irrigation monitoring, irrigation scheduling, and water resource management. Information about components of water budget for the experimental fields is displayed for cropping year 2018 (Figure 4a) and 2019 (Figure 4b). During 2018, no irrigation was applied till mid-July, as crop water requirements were fulfilled through rainfall. In July, one supplemental irrigation was applied to maintain the $40 \%$ depletion of field capacity in soil. In July, several rainfall events occurred to replenish the crop water requirements. Three irrigations were applied in the month of September 2018, which was relatively a direr month as compared to other months of the study period. Frequent rainfall events fulfilled the crop water requirements, making saturation in soil close to its field capacity for several days of October 2018 (Figure 4a).

In 2019, frequent rainfall events in the months of June, July, September, and October satisfied the crop water needs and required no supplemental irrigation. Relatively less rainfall events occurred in the months of June, July, and August. However, no irrigation was applied till mid-July 2019 because of relatively low water needs by potato crop in its initial stage, as well as at least $40 \%$ maintained depletion levels of soil field capacity. Five irrigations of the calculated depths were applied in late July and three weeks of August, to maintain the desired moisture levels in soil (Figure 4b). From late August to October 2019, three heavy rainfall events occurred (>50 $\mathrm{mm}$ ) and helped fulfill the potato crop's irrigation water requirements or consumptive use.

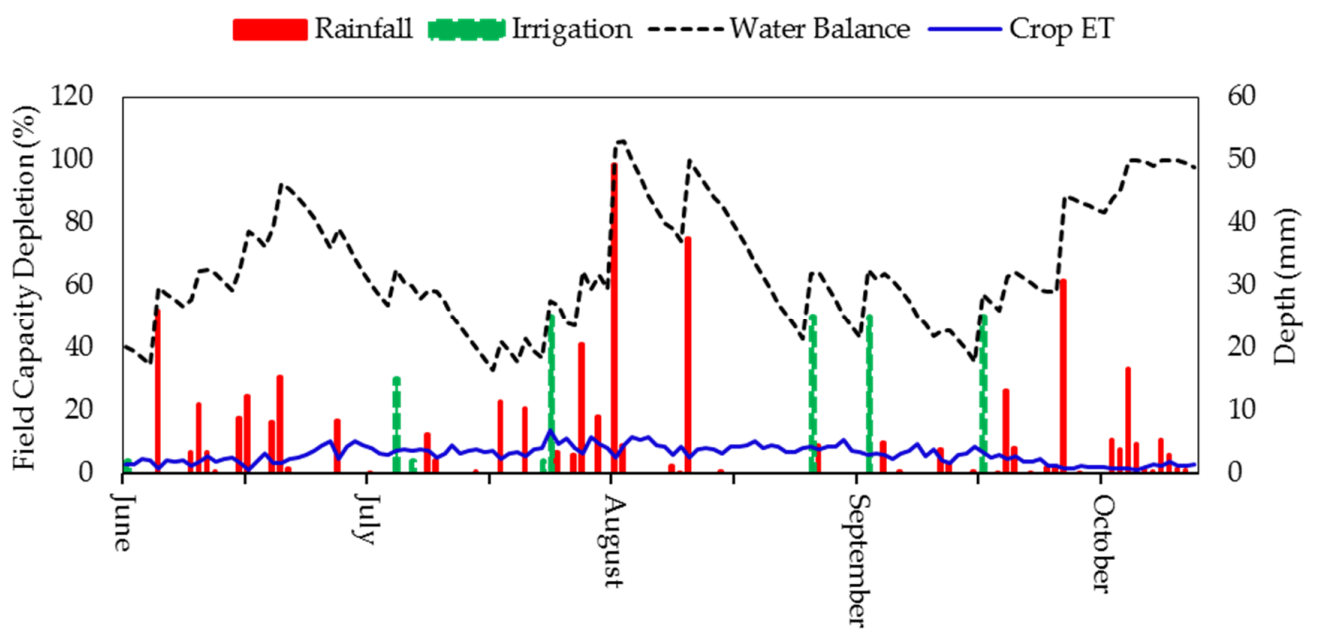

(a)

Figure 4. Cont. 


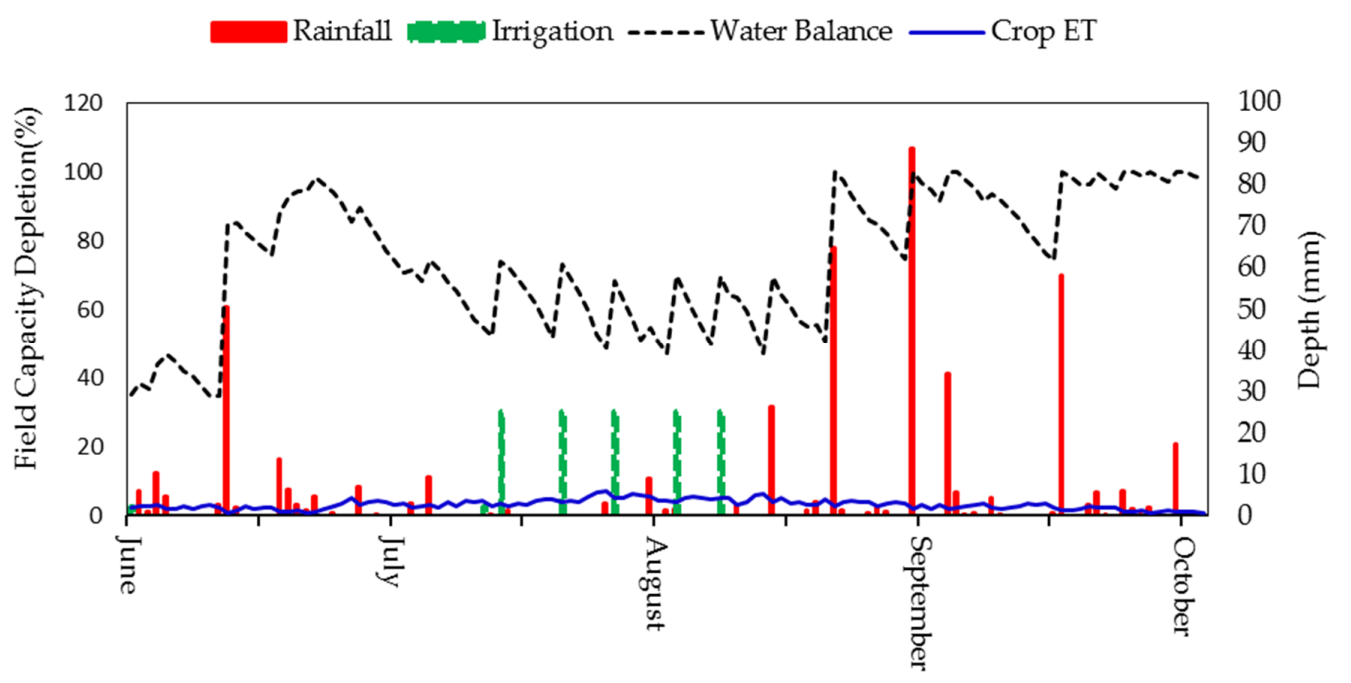

(b)

Figure 4. Budgeting of water for the experimental fields using water data for years (a) 2018 and (b) 2019.

\subsection{Water Productivity}

Figure 5 represents the water productivities for different irrigation systems in years 2018 and 2019. In 2018, the highest water productivity (e.g., $1.4174 \mathrm{~kg} / \mathrm{m}^{3}$ ) was recorded for the fertigation system in comparison with other irrigation methods. In 2019, a similar trend to the previous year was observed for the fertigation and sprinkler irrigation systems, e.g., the highest $\left(1.53 \mathrm{~kg} / \mathrm{m}^{3}\right)$ and the lowest $\left(1.19 \mathrm{~kg} / \mathrm{m}^{3}\right)$ water productivities for these treatments, respectively.

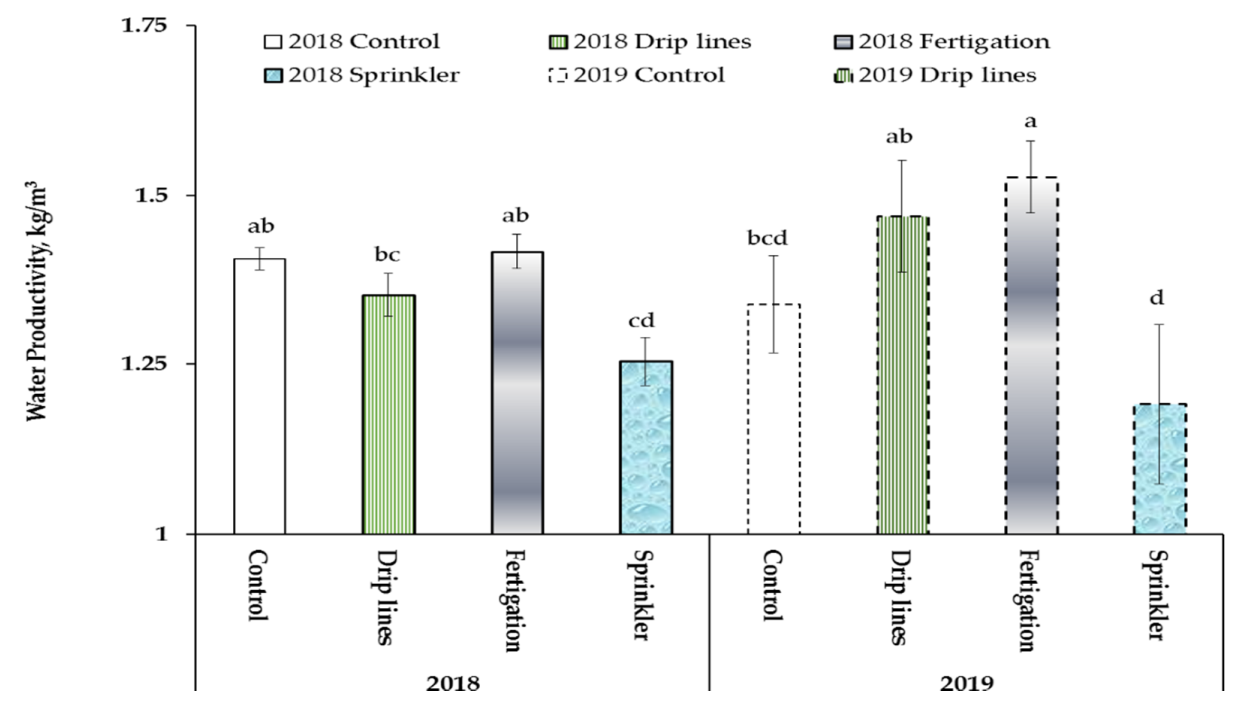

Figure 5. Water productivities for different irrigation systems in 2018 and 2019.

\subsection{Payout Returns}

In 2018, the highest payouts per hectare were calculated for the sprinkler irrigation system, e.g., \$6786.7 CAD/hectare (Figure 6). The highest percentages of marketable potatoes were the major reason for higher financial gains for the sprinkler irrigation system. Instead of the lowest potato tuber yield in case of drip irrigation system in 2018, the mean payout per hectare was 211.1 CAD/hectare higher than the control treatment. The higher payout for the drip irrigation system indicated that the timely irrigation impacted the potato tuber development and quality. Similarly, higher payout was recorded for fertigation system also in 2018; e.g., \$5227.1 CAD/hectare. In 2019, the highest 
financial gain was attained by the drip irrigation system, e.g., $\$ 6503.95 \mathrm{CAD} /$ hectare, which was $\$ 2104.55 \mathrm{CAD} /$ hectare higher than control treatment. Similarly, sprinkler and fertigation treatments earned $\$ 6062.77 \mathrm{CAD} /$ hectare and $\$ 6408.8 \mathrm{CAD} /$ hectare respectively, which were $\$ 237.77 \mathrm{CAD} /$ hectare and $\$ 329.9 \mathrm{CAD} /$ hectare higher than the control treatment, respectively (Figure 6).

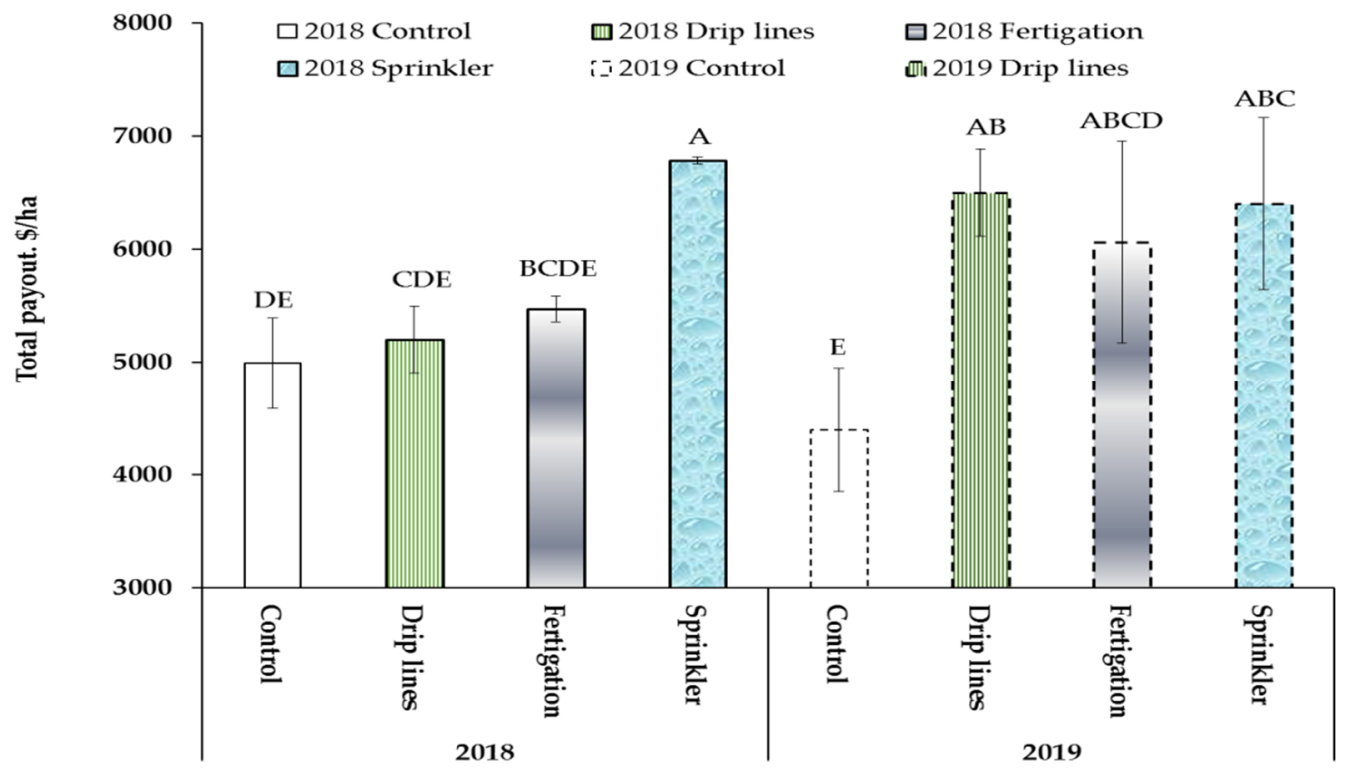

Figure 6. Payout per hectare for different irrigation systems in 2018 and 2019.

\subsection{Effects of Irrigation Methods and Years}

A two-way ANOVA was run to examine the effects of irrigation methods and year on potato tuber yield and quality. There was a significant interaction (irrigation method $\mathrm{x}$ year) on potato tuber yield, $p=0.012$, indicating at least one statistically different irrigation method $\mathrm{x}$ year combination. Simple main effects analysis showed that there was a significant effect of irrigation methods and year on potato tuber yield (Table 4). However, in the case of significant interaction, it is advisable to consider the interactions effect only by ignoring the main effects. Table 4 represents all the possible combinations of irrigation methods and year combinations.

Table 4. Two-way analysis of variance table for statistical comparison.

\begin{tabular}{|c|c|c|c|c|c|}
\hline Response Variable & Sources & Degree of Freedom & Mean Square & F-Value & $p$-Value \\
\hline \multirow{5}{*}{$\begin{array}{l}\text { Potato tuber yield } \\
\qquad(\mathrm{kg} / \mathrm{ha})\end{array}$} & Year & 1 & $36,955,884$ & 15.3 & 0.001 \\
\hline & Irrigation Methods & 3 & $20,380,293$ & 8.43 & 0.001 \\
\hline & Year $x$ Irrigation Methods & 3 & $10,966,955$ & 4.54 & 0.012 \\
\hline & Error & 23 & $2,417,954$ & & \\
\hline & Total & 30 & & & \\
\hline \multirow{5}{*}{$\begin{array}{c}\text { Marketable potatoes } \\
\qquad(\%)\end{array}$} & Year & 1 & 2975.95 & 100 & 0 \\
\hline & Irrigation Methods & 3 & 202.35 & 6.80 & 0.002 \\
\hline & Year x Irrigation Methods & 3 & 28.96 & 0.97 & 0.422 \\
\hline & Error & 23 & 29.74 & & \\
\hline & Total & 30 & & & \\
\hline \multirow{5}{*}{$\begin{array}{l}\text { Total payout per } \\
\text { hectare (Dollars) }\end{array}$} & Year & 1 & 163,220 & 1.66 & 0.211 \\
\hline & Irrigation Methods & 3 & $1,859,110.23$ & 19.0 & 0 \\
\hline & Year x Irrigation Methods & 3 & $612,896.7$ & 6.23 & 0.003 \\
\hline & Error & 23 & $98,435.5$ & & \\
\hline & Total & 30 & & & \\
\hline \multirow{5}{*}{$\begin{array}{l}\text { Water Productivity } \\
\qquad\left(\mathrm{kg} / \mathrm{m}^{3}\right)\end{array}$} & Year & 1 & 0.004427 & 1.24 & 0.276 \\
\hline & Irrigation Methods & 3 & 0.081653 & 23.0 & 0 \\
\hline & Year $x$ Irrigation Methods & 3 & 0.020386 & 5.73 & 0.004 \\
\hline & Error & 23 & 0.003557 & & \\
\hline & Total & 30 & & & \\
\hline
\end{tabular}




\section{Discussion}

\subsection{Quality of Tuber}

Overall, higher percentages of marketable potatoes were recorded in the year 2019, in comparison with the year 2018. The highest percentages of marketable potatoes were recorded for the sprinkler irrigation system for 2019 (82.2\%), in comparison with the year 2018 (64.3\%). The lowest percentages of marketable potatoes were recorded for control treatment in both years, indicating that the irrigation played an important role during tuber development stages.

\subsection{The Drought Periods}

Less available rains during July and August in Prince Edward Island cause drought conditions for potato fields that adversely affect tuber yield if no supplemental irrigation is scheduled and applied [5-8]. The negative values indicate the higher values of ETo then rainfall. In the month of August, ETo surpassed rainfall in year 2012, 2013, 2015, 2016, and 2017 by 46.08, 29.97, 4.39, 15.83, and $39.64 \mathrm{~mm}$, respectively. In the months of September, October, and November, rainfall surpassed ETo, reflecting the availability of water when the potato fields needed irrigation.

The data of ETo provided useful information in water management for larger areas; however, for irrigation scheduling of a specific crop, $\mathrm{ET}_{\mathrm{C}}$ is required. In the cropping year 2019, a relatively lower amount of rainfall occurred during the months of July and August as compared to 2018. During the growing season of 2019, the gaps between rainfall and ETc were substantial in the months of August and September. In the month of October, crop water requirements were fulfilled, and no supplemental irrigation was required.

\subsection{Effects of Irrigations Applications Systems on Water Productivity}

During the 2018 growing season, the lowest water productivity was recorded for the sprinkler irrigation system, as this system consumed 6.8 times more water than the drip and fertigation systems. The water productivity of the drip irrigation system was less than control treatment, i.e., $1.35 \mathrm{~kg} / \mathrm{m}^{3}$. The non-uniform germination of potato plants in drip replication plots and the resultant asymmetrical alignment of drip emitters with potato plants in 2018 might be the cause of low water productivity for the drip irrigation system during this year. In 2019, higher water productivity $\left(1.47 \mathrm{~kg} / \mathrm{m}^{3}\right)$ was observed for the drip irrigation system in comparison with year $2018\left(1.35 \mathrm{~kg} / \mathrm{m}^{3}\right)$, as the alignments of drip emitters were adjusted with the growth of potato plants. This can be recommended as one of the best management practices and/or techniques for efficient potato cultivation under drip irrigation system.

\subsection{Effects of Irrigations Applications Systems and Growing Years}

Several 'irrigation method x year' combinations were found to be significant with regard to their effect on tuber yield. There were no significant differences between irrigation methods and control treatment in 2018. However, results of several treatments of 2018 were significantly different with 2019 treatments. For example, potato tuber yield in 2018 for control treatment was significantly higher than in 2019. The lower amount of rainfall in the months of July and August in 2019 justifies the lower potato tuber yield for the control treatment. In contrast to the control treatment, the sprinkler irrigation system yielded significantly higher in 2018 than in 2019. Potato tuber yield of sprinkler-2019, fertigation-2019, drip-2019 was significantly higher than the control-2018 treatment. Similarly, potato tuber yield of Fertigation-2018, drip 2019 was significantly higher than that of control-2019 (Table 4). The results suggested that the sprinkler irrigation system performed better in 2018 and fertigation system performance was better in 2019. However, based on statistical analysis, no irrigation system performed consistently better in the two consecutive years, to give a higher potato tuber yield.

Results of the two-way ANOVA to examine the effects of irrigation methods and year on potato tuber quality suggested a non-significant interaction of irrigation method x year $(p=0.422)$. Simple main effects analysis showed that there was a significant effect $(p=0.002)$ of irrigation methods on potato 
quality, indicating that at least one irrigation method performed significantly different than the other irrigation methods. Further analysis suggested that the sprinkler and fertigation systems yielded higher percentages of marketable potatoes than the control treatment. However, no significant differences were observed between drip and control treatments. Similarly, no significant differences were observed between sprinkler and fertigation systems. Main effect analysis also showed that there was a significant effect $(p=0.0)$ of year on potato quality, indicating that, in one year, the irrigation method yielded better quality potatoes than in the other year. Further analysis of multiple means comparison suggested that, in the year 2019, the percentages of marketable potatoes was significantly higher than in 2018.

There was a significant interaction of 'irrigation method $\mathrm{x}$ year' $(p=0.003)$ on payout returns. In 2018, sprinkler payout returns were significantly higher than drip, fertigation, and control treatments. However, no significant differences of payout returns were observed between control, drip, and fertigation treatments in 2018. The higher payout returns of sprinkler irrigation system were due to higher percentages of marketable potatoes yielded from this treatment. Furthermore, all the irrigation methods had the significantly higher payout returns than the control treatment in 2019. However, no statistical differences of payout returns were observed between sprinkler, drip, and fertigation treatments in 2019.

A similar significant interaction of 'irrigation method $\mathrm{x}$ year' $(p=0.004)$ on water productivity was observed as for payout returns and tuber yield. The water productivity of fertigation in 2018 was significantly higher than the control and sprinkler irrigation systems may be the lower water consumption as well as higher yield of this treatment in comparison with control and sprinkler treatments.

\section{Conclusions}

This study evaluates the benefits of using irrigation scheduling and supplemental irrigation for sustainable irrigation water management in potato fields. The Penman-Monteith modified method was used to test whether the rainfall is enough for sustainable potato production in Prince Edward Island, or if supplemental irrigation is needed, in addition to rainfall. The result highlighted the cumulative gaps between rainfall and crop evapotranspiration in the months of August and September due to higher value of crop coefficient factor resulting into higher crop water requirements. Pressurized irrigation systems, including sprinkler, fertigation and drip irrigation, were installed to evaluate the impact of scheduled supplemental irrigation to offset deficits in irrigation, as compared to conventional practice of rainfed conditions. A two-way ANOVA examined the effect of irrigation methods and year on potato tuber yield, water productivity, payout returns, and potato quality. A significant interaction (irrigation methods $x$ year) was recorded on potato tuber yield, indicating at least one significantly different combination than the other. The sprinkler and fertigation systems performed better than other irrigation systems during both years of the study. In term of payout returns and potato tuber quality, the sprinkler irrigation treatment performed significantly better than the other three treatments. However, in terms of water productivity, the fertigation system performed significantly better than the others in both years. It is concluded that the choice of irrigation methods largely affects water budget of the system and may be chosen based on the months and specific crop water requirements, to ensure sustainable use of water resources.

Author Contributions: Conceptualization, H.A., A.A.F., and F.A.; methodology, H.A. and F.A.; software, H.A. and F.A.; validation, A.A.F.; formal analysis, A.A.F., B.A., and T.E.; investigation, H.A. and F.A.; resources, A.A.F.; data curation, H.A., B.A., and T.E.; writing-original draft preparation, H.A. and A.A.F.; writing-review and editing; B.A., and T.E.; supervision, A.A.F.; project administration, A.A.F. and F.A.; funding acquisition, A.A.F. All authors have read and agreed to the published version of the manuscript.

Funding: This research was supported by the Natural Science and Engineering Research Council of Canada.

Acknowledgments: The authors thank Andrew MacEwen, Nazar Hussain, Charles Terrio, William Hardy, Miehle Helga, Newton Yorinori, and the Precision Agriculture Team at the University of Prince Edward Island for their cooperation and assistance during the experiment. 
Conflicts of Interest: The authors declare no conflict of interest.

\section{References}

1. Food and Agriculture Organization of the United Nations. Available online: http://www.fao.org/news/ archive/news-by-date/2011/en/ (accessed on 17 November 2019).

2. Fabeiro, C.; Martín De Santa Olalla, F.; De Juan, J.A. Yield and size of deficit irrigated potatoes. Agric. Water Manag. 2001, 48, 255-266. [CrossRef]

3. MacDonald, M. Potatoes: A Billion Dollar Industry for P.E.I. Available online: https://www.theguardian.pe. ca/news/local/potatoes-a-billion-dollar-industry-for-pei-95098/ (accessed on 15 January 2020).

4. Agriculture and Agri Food Canada Potato Market Information Review 2013-2014. Available online: https:/www5.agr.gc.ca/eng/industry-markets-and-trade/canadian-agri-food-sector-intelligence/ horticulture/horticulture-sector-reports/potato-market-information-review-2016-2017/?id=1536104016530 (accessed on 17 November 2019).

5. Food and Agriculture Organizations of United Nations Potato. Available online: http://www.fao.org/landwater/databases-and-software/crop-information/potato/en/ (accessed on 17 November 2019).

6. Van Loon, C.D. The effect of water stress on potato growth, development, and yield. Am. Potato J. 1981, 58, 51-69. [CrossRef]

7. Shock, C.C.; Feibert, E.B.G.; Saunders, L.D. Potato yield and quality response to deficit irrigation. HortScience 1998, 33, 655-659. [CrossRef]

8. Ojala, J.C.; Stark, J.C.; Kleinkopf, G.E. Influence of irrigation and nitrogen management on potato yield and quality. Am. Potato J. 1990, 67, 29-43. [CrossRef]

9. Government of Prince Edward Island. Climate Change and Island Agriculture. Available online: https://www.princeedwardisland.ca/en/information/communities-land-and-environment/climatechange-and-island-agriculture (accessed on 17 November 2019).

10. Bélanger, G.; Walsh, J.R.; Richards, J.E.; Milburn, P.H.; Ziadi, N. Yield response of two potato cultivars to supplemental irrigation and $\mathrm{N}$ fertilization in New Brunswick. Am. J. Potato Res. 2000, 77, 11-21. [CrossRef]

11. Porter, G.A.; Opena, G.B.; Bradbury, W.B.; McBurnie, J.C.; Sisson, J.A. Soil management and supplemental irrigation effects on potato: I. Soil properties, tuber yield, and quality. Agron. J. 1999, 91, 416-425. [CrossRef]

12. Opena, G.B.; Porter, G.A. Soil management and supplemental irrigation effects on potato: II. Root growth. Agron. J. 1999, 91, 426-431. [CrossRef]

13. Allen, W.H.; Lambert, J.R. Application of the principle of calculated risk to scheduling of supplemental irrigation, I. concepts. Agric. Meteorol. 1971, 8, 193-201. [CrossRef]

14. López-Urrea, R.; Martín de Santa Olalla, F.; Fabeiro, C.; Moratalla, A. Testing evapotranspiration equations using lysimeter observations in a semiarid climate. Agric. Water Manag. 2006, 85, 15-26. [CrossRef]

15. Abdullah, S.S.; Malek, M.A.; Abdullah, N.S.; Kisi, O.; Yap, K.S. Extreme Learning Machines: A new approach for prediction of reference evapotranspiration. J. Hydrol. 2015, 527, 184-195. [CrossRef]

16. Allen, R.G.; Pereira, L.S.; Raes, D.; Smith, M. Crop evapotranspiration - Guidelines for computing crop water. FAO Irrigation and drainage paper 56. FAO Rome 1998, 300, D05109.

17. Kashyap, P.S.; Panda, R.K. Evaluation of evapotranspiration estimation methods and development of crop-coefficients for potato crop in a sub-humid region. Agric. Water Manag. 2001, 50, 9-25. [CrossRef]

18. Onder, S.; Caliskan, M.E.; Onder, D.; Caliskan, S. Different irrigation methods and water stress effects on potato yield and yield components. Agric. Water Manag. 2005, 73, 73-86. [CrossRef]

19. Stylianou, Y.; Orphanos, P.I. Irrigation of potatoes by sprinklers or tricklers on the basis of pan evaporation in a semi-arid region. Potato Res. 1981, 24, 159-170. [CrossRef]

20. Ünlü, M.; Kanber, R.; Şenyigit, U.; Onaran, H.; Diker, K. Trickle and sprinkler irrigation of potato (Solanum tuberosum L.) in the Middle Anatolian Region in Turkey. Agric. Water Manag. 2006, 79, 43-71. [CrossRef]

21. Trifonov, P.; Lazarovitch, N.; Arye, G. Water and nitrogen productivity of potato growth in desert areas under low-discharge drip irrigation. Water 2018, 10, 970. [CrossRef]

22. Waddell, J.T.; Gupta, S.C.; Moncrief, J.F.; Rosen, C.J.; Steele, D.D. Irrigation and nitrogen management effects on potato yield, tuber quality, and nitrogen uptake. Agron. J. 1999, 91, 991-997. [CrossRef] 
23. Ierna, A.; Pandino, G.; Lombardo, S.; Mauromicale, G. Tuber yield, water and fertilizer productivity in early potato as affected by a combination of irrigation and fertilization. Agric. Water Manag. 2011, 101, 35-41. [CrossRef]

24. Abbas, F.; Farooque, A.A.; Afzaal, H. Homogeneity in Patterns of Climate Extremes Between Two Cities-A Potential for Flood Planning in Relation to Climate Change. Water 2020, 12, 782. [CrossRef]

25. Afzaal, H.; Farooque, A.A.; Abbas, F.; Acharya, B.; Esau, T. Groundwater Estimation from Major Physical Hydrology Components Using Artificial Neural Networks and Deep Learning. Water 2019, 12, 5. [CrossRef]

26. Wilson, C.A.; Davidson, D.A.; Cresser, M.S. Multi-element soil analysis: An assessment of its potential as an aid to archaeological interpretation. J. Archaeol. Sci. 2008, 35, 412-424. [CrossRef]

27. Patterson, G.T.; Carter, M.R. Soil Sampling and Methods of Analysis, 2nd ed.; Carter, M.R., Gregorich, E.G., Eds.; CRC Press Taylor \& Francis Group: Boca Raton, FL, USA, 2007; Volume 44, ISBN 9780849335860.

28. Heiri, O.; Lotter, A.F.; Lemcke, G. Loss on ignition as a method for estimating organic and carbonate content in sediments: Reproducibility and comparability of results. J. Paleolimnol. 2001, 25, 101-110. [CrossRef]

29. Ierna, A.; Mauromicale, G. Potato growth, yield and water productivity response to different irrigation and fertilization regimes. Agric. Water Manag. 2018, 201, 21-26. [CrossRef]

30. Pereira, L.S.; Cordery, I.; Iacovides, I. Improved indicators of water use performance and productivity for sustainable water conservation and saving. Agric. Water Manag. 2012, 108, 39-51. [CrossRef]

31. Prince Edward Island-Fisheries and Agriculture. Nutrient Recommendation. Available online: https://www. princeedwardisland.ca/sites/default/files/publications/af_nutrient_recommendation_tables_.pdf (accessed on 16 February 2020).

32. United States Department of Agriculture Potatoes for Processing. Available online: http://www.ascr.usda. gov/complaint_filing_file.html (accessed on 12 March 2020).

33. Afzaal, H.; Farooque, A.A.; Abbas, F.; Acharya, B.; Esau, T. Computation of Evapotranspiration with Artificial Intelligence for Precision Water Resource Management. Appl. Sci. 2020, 10, 1621. [CrossRef]

(C) 2020 by the authors. Licensee MDPI, Basel, Switzerland. This article is an open access article distributed under the terms and conditions of the Creative Commons Attribution (CC BY) license (http://creativecommons.org/licenses/by/4.0/). 